\title{
The Mediating Role of Job Satisfaction in the Hospital
}

\author{
Fairynda Novarian, Abdul Haeba Ramli* \\ Magister of Arrangement \\ Universitas Trisakti \\ Jakarta, Indonesia \\ *abdul.haeba@trisakti.ac.id
}

\begin{abstract}
This watchfulness is aimed to analyze the effect of Emotional Intelligence to Job performance through job satisfaction. The watchfulness was implemented with 251 of sample from Private Hospital. The collected data was analyzed using SPSS and SEM-Lisrel to verify the hypothesis. The result was Emotional Intelligence has positive and significant towards Job performance and Job satisfaction, then Job satisfaction have positive effects and significant towards Job performance, and employee job satisfaction has mediating effect midst Emotional Intelligence also employee performance. Practical implementation from this watchfulness suggest that the company can implemented the strategy to increase the Job performance based on the company strategy by Emotional Intelligence.
\end{abstract}

Keywords-emotional intelligence, employee performance, job satisfaction, and private hospital

\section{INTRODUCTION}

The infirmary system itself is a labor-intensive sector that has experienced many changes as a result of increasing competition. The plea for infirmary continues to grow as a result of population growth, increasing aging population, advances in the supply of medicines, and technological growth $[1,2]$. By comprehending future developments, infirmary providers are progressively facing defiance's to arrange expenses as well as provide better services and better outcomes for patients [3-5].

The infirmary workers are ones of the main and greatly prominent components of health services [2]. In the infirmary treatment industry where fruitfulness is redounded by sufferer satisfaction, employees who are involved and satisfied are the best factors to fulfill the plea for grade sufferer care [6]. Therefore, the greatly notable impact on the infirmary industry will be the yield of the community who labor in it [7]

The hospital itself is crucial in the infirmary system. In hospitals, human resource arrangement has a special role, personnel performance has a direct impact on the grade and effectiveness of medical treatments. The importance of human resources in the provision of medical services has also been established in WHO publication which includes human resources as one of the three prominent forms of capital needed for the provision of medical services [1]

Based on an interview with one of the staff who worked at the Imanuel Hospital Lampung before, found complaints that had been expressed about their workloads that adhere to emotional states and ultimately impact on their performances. In adjunct, interviews were also conducted with three patients at the Imanuel Hospital a few months earlier, and they complained about the Imanuel Hospital staff who were less responsive to patients. Therefore, watchfulness on human resources in Imanuel Hospital is needed to analyze the workers' job performance by taking into account the influencing factors, namely Emotional Intelligence.

Emotional Intelligence can improve Job Performance of human resources [8]. Human resources with high Emotional Intelligence can regulate their emotions and mental positively so as to provide better Profession Performance [9]. On the other hand, low Emotional Intelligence can make a bad impact, so that human resources cannot decide the proposition rationally and ultimately can adversely govern Profession Performance.

In adjunct to the Emotional Intelligence factor, one of the variables that govern labour Profession Performance is Job Satisfaction [10]. Likewise, with the other studies with results that confirm previous watchfulness that Job Satisfaction governs Profession Performance of employees [11-15].

This encourages the author to conduct watchfulness on human resources in hospital services to analyze their job performance by taking into account the factors that influence it, namely Emotional Intelligence, with Job Satisfaction as a mediator variable.

\section{LITERATURE REVIEW}

\section{A. Emotional Intelligence}

Emotional Intelligence is a draught that tries to associate emotions, cognition, and metacognitive method [16]. It was also stated earlier that Emotional Intelligence is the proficiency to comprehend and express affects, assimilate affects in the 
mind, comprehend and reasons with emotions, and organize emotions in self and others [17].

The draught of Emotional Intelligence is elucidated as the strength to think about affects, and affects to augment musing [18]. A person is considered competent in the perception of emotions if he is able to recognize other community's responses and be conscious of his own affect states and responses [19]. It's a strong skill to comprehend one's own affects, the effects of others, the causes and consequences of this emotion [20]. Thus empathy, proposition solving, hopefulness, and self-consciousness that enable community to comprehend, delineate on, and respond to sundry environmental circumstances is concerned to Affect Intelligence.

\section{B. Job Satisfaction}

Job Satisfaction is the draught of personal appraisement of the shapes that exist in the profession or the results obtained from having a profession [21]. Job Satisfaction must be considered a mandatory attribute that is very often measured by organizations to ensure there is a compassionate employee approach to the tasks and responsibilities they face.

Job Satisfaction refers to an individual's multidimensional psychological response to their work [22]. This is supported by some opinions that say Profession Satisfaction is an affect, psychological and environmental shape, common attitudes and feelings that labor have towards their work [23]. This is strongly influenced by labor insight regarding their sundry missions. It's considered not only as a common attitude and feeling of labor towards work [24], but which is accepted as an emotional response from a broader perspective [25].

\section{Job Performance}

Job Performance or better known is a draught commonly used in industrial and organizational psychology. Employees' Job Performance is basically the yield of a series of conducts [26]. This can be redounded as a diversity of assignments implemented every day. And other opinions about Job Performance are concerned to what individual workers do or don't do [27]. Job Performance itself is a term that refers to the grade of an employee's work [28]. It's refers to how community do their work.

So, it is mentioned that Job Performance as an employee work performance utilizes the skills, knowledge, and dedication needed to obtain meaningful work is done well [29]. In adjunct, Job Performance can be described as the count of assignment as well as the grade and quantity of yield, or more commonly about how well a labor can perform assignments given at work [30].

\section{Hypothesis Development Watchfulness}

In a previous study of academic administrators at three universities in Malaysia found a positive and notable relationship midst Emotional Intelligence and Job performance [31]. Likewise, other studies also reported a good influence caused by good employee Emotional Intelligence on Job Performance of the employees [32]. In line with other studies, also found a direct and positive relationship midst Emotional Intelligence and Job performance [33]. Based on this information, the formulation of the watchfulness hypothesis is:

$\mathrm{H1}$ : Emotional Intelligence has a positive and significant influence on Job Performance.

In a study of the employees of multinational organizations in India, it was found that Emotional Intelligence had a direct relationship with Job Satisfaction [34]. Other watchfulness also found that employees with high Emotional Intelligence would produce good Job Satisfaction [35]. Then, further watchfulness found a positive impact caused by employees' Emotional Intelligence on job satisfaction [36]. Based on this information, the formulation of the watchfulness hypothesis is:

$\mathrm{H} 2$ : Emotional Intelligence has a positive and significant effect on Job Satisfaction.

Based on the yields of watchfulness conducted on employees who assignment in the Automotive industry, Punjab, India it's stated that employees who have Job Satisfaction will produce good job performance [37]. That confirmed other watchfulness that found a direct significant relationship midst Job Satisfaction and Job Performance [38]. And previous watchfulness also suggested that Job Satisfaction has a positive impact on Job Performance [39]. Based on this information, the formulation of the watchfulness hypothesis is:

H3: Job Satisfaction has a positive and significant influence on Job performance.

In watchfulness conducted on employees of the University of Jordan, it was shown that those who have higher Emotional Intelligence have better performance, because those who have higher Emotional Intelligence are commonly more contented with their work and those who are more contented with their work perform better than those who are less contented with their work [40]. It also supports the previous watchfulness which states that good employees' Emotional Intelligence will have a positive impact on their Job Satisfaction which then also has a significant and positive impact on Job Performance [41]. Based on this information, the formulation of the watchfulness hypothesis is:

H4: Emotional Intelligence has a positive and significant effect on Job Performance with Job satisfaction as a mediating variable.

\section{METHODS}

Data and hypotheses analyzing on this watchfulness are using Structural Equation Model (SEM) statistical analysis tools with the Linear Structural Relationship (LISREL) program. The population in this study conducted in October to December at the Private Hospital in Lampung are employees, consisting of: doctors, nurses, operators, pharmacy staff, admin / and others. Sampling itself is done using the sampling method used by Hair, et al. That the number of samples is five to ten 
times the total watchfulness indicators, this study using twentyseven indicators, so that the minimum sample size is 135 (one hundred thirty-five) [42]. The number of questionnaires distributed was 300. Questionnaires that were lost and / or not returned by prospective respondents were 47 and 2 were returned but were not filled in completely, so the questionnaire that was returned to the author and filled out completely was 251

In this study each statement was given a choice of five score answers on a Likert scale. The Emotional Intelligence variable is measured by submitting 16 statements divided into four dimensions [43], the Job Satisfaction variable is measured by three indicators [44], which were then developed in 2013 [44] and the Job performance variable is measured using eight indicators [45].

From the yields of the validity verify of the Emotional Intelligence variable after going through 11 stages to get the value of the appropriate goodness of fit, there are 6 Valid Indicators namely EI2, EI11, E13, EI14, EI15, EI16.

From the yields of the validity verify shows that Job Satisfaction variable model is saturated, which means that the variable model has a good overall goodness of fit, thus indicating that all three indicators are valid. And the yields of the validity verify of Job Performance variables are known after going through 5 stages to get the appropriate goodness of fit value, there are 4 Valid Indicators namely JP2, JP3, JP6 and JP8.

In verifying the reliproficiency of the Emotional Intelligence, Job Satisfaction, and Job Performance variables, respectively, the Cronbach's Alpha scores are 0.825, 0.807, 0, 912 , and 0.891 where $>0.6$, which means all indicators used in the variables used in this study have good reliproficiency and respondents' answers to the statements given in these variables can be answered properly and consistently by the respondents [46].

Before analyzing further on hypothesis verifying, the model goodness of fit verifies in table 1 is first showed:

TABLE I. GOODNESS OF FIT VERIFY YIELDS

\begin{tabular}{|c|l|l|l|}
\hline Category & \multicolumn{1}{|c|}{ Indeks } & \multicolumn{1}{c|}{$\begin{array}{c}\text { Level of } \\
\text { acceptance }\end{array}$} & Information \\
\hline \multirow{3}{*}{ 1. Absolute Fit } & Chisquare & 0,0 & Model Poor Fit \\
\cline { 2 - 4 } & RMSEA & 0,084 & Model Fit \\
\cline { 2 - 4 } & GFI & 0,95 & Model Fit \\
\hline \multirow{3}{*}{ 2. Incremental Fit } & AGFI & 0,80 & Model Poor Fit \\
\cline { 2 - 4 } & CFI & 0,94 & Model Fit \\
\cline { 2 - 4 } & TLI (NNFI) & 0,93 & Model Fit \\
\cline { 2 - 4 } & NFI & 0,91 & Model Fit \\
\hline 3.Parsimonious fit & Chisq/df & 2,74 & $<5.0$. \\
\hline
\end{tabular}

Based on the opinion which says that to measure goodness of fit at least one index is used from each category and based on the satisfaction of table 10 which shows that GFI is from the Absolute Fit category, CFI from the Incremental Fit category, and Chi-square / df in the category $[42,47]$. Parsimonious Fit is recommended because it is often reported in the literature with GFI, CFI, and Chi-square / df yields respectively 0.95, 0.94, and 2.74. Then the model is worthy of further analysis so that further hypothesis verifying can proceed.

\section{RESULTS AND DISCUSSION}

\section{A. Results}

The yields of data processing are implemented to verify the hypothesis, as described in Table 2 below:

TABLE II. HYPOTHESIS TESTING

\begin{tabular}{|l|l|l|l|}
\hline \multicolumn{1}{|c|}{ Hypothesis } & Coefficient & $\begin{array}{c}\text { P- } \\
\text { value }\end{array}$ & Decision \\
\hline $\begin{array}{l}\text { H1: Emotional intelligence has a } \\
\text { positive and significant influence } \\
\text { on Work Performance }\end{array}$ & 0,47 & 0,00 & Supported \\
\hline $\begin{array}{l}\text { H2: Emotional Intelligence has a } \\
\text { positive and significant impact on } \\
\text { Job Satisfaction }\end{array}$ & 0,38 & 0,00 & Supported \\
\hline $\begin{array}{l}\text { H3: Job Satisfaction has a positive } \\
\text { but not significant effect on Job } \\
\text { performance. }\end{array}$ & 0,06 & 0,20 & $\begin{array}{l}\text { Not } \\
\text { supported }\end{array}$ \\
\hline $\begin{array}{l}\text { H4: Emotional Intelligence has a } \\
\text { positive and significant effect on } \\
\text { Job Performance with / through Job } \\
\text { satisfaction as a mediating variable }\end{array}$ & 0,07 & 0,00 & Supported \\
\hline
\end{tabular}

\section{B. Discussion}

The first hypothesis, based on the yields, a positive coefficient $=0.47$ and a significance value ( $p$-value) is 0.00 are obtained. It shows that Emotional Intelligence has a positive and significant effect on Job Performance. Thus, the first hypothesis is accepted.

The second hypothesis, based on the yields, positive coefficient value $=0.38$ and a significance value ( $p$-value) of 0.00 are obtained. It shows that Emotional Intelligence has a positive and significant effect on Job Satisfaction. Thus, the second hypothesis is accepted.

The third hypothesis, based on the yields, positive coefficient $=0.06$ but the significance value ( $\mathrm{p}$-value) of 0.20 (greater than 0.05) are obtained. It shows that Job Satisfaction has a positive but not significant effect on Job Performance. Thus, the third hypothesis is rejected.

The fourth hypothesis, based on the yields of verifying the mediation effect of Job Satisfaction, the $\mathrm{z}$-value $=84.61$ (greater than $\mathrm{z}$-table $=1.96)$ with a positive coefficient $=0.07$ and a significance value ( $p$ value) of 0.00 . So, it shows that Job Satisfaction mediates the influence of Emotional Intelligence on Job Performance. Thus, the fourth hypothesis is accepted. 


\section{CONCLUSIONS}

Based on the findings and verifying of hypotheses that have been explained, several conclusions can be drawn from the yields of this study: (1) There is a positive and significant influence midst Emotional Intelligence on Job Performance. (2) There is a positive and significant influence midst Emotional Intelligence on Job Satisfaction. (3) There is a positive but not significant effect midst Job Satisfaction on Job Performance. (4) And there is a positive and significant influence midst Emotional Intelligence on Job Performance through Job Satisfaction.

The yields of this study indicate to arrangement to determine the direction of policy towards the arrangement of human resources, especially in the field of health services to improve Job Performance and Job Satisfaction for employees who provide health services such as in Hospitals, which is the main factor moving competition forward very tight business. Either by conducting training regularly or by coaching periodically so that employees are able to increase the level of Emotional Intelligence, so they can assess their emotions (Selfemotion appraisal), assess the emotions of others, and be able to use and organize their own emotions. This might help monitor the development of habits towards employee conduct to improve Emotional Intelligence.

This watchfulness proves that if employees already have a high level of Emotional Intelligence, then their optimal work performance and satisfaction will be obtained. Suggestions that can be given to further watchfulness for future watchfulness is to add more supporting variables that form Job Performance, so that it is enriching more findings about factors that influence Job Performance, for example with the Person-organizational fit [48], Job stress [7], career development variables [49] and Organizational commitment [50]. This watchfulness was conducted on the object of watchfulness on health services such as hospitals, so that watchfulness could further develop other watchfulness objects such as other service industries or manufacturing industries, and other industries.

\section{REFERENCES}

[1] World Health Organization, "World Report on Ageing and Health," [online]. Retrieved from http://www.who.int/ageing/events/worldreport-2015-launch/en/.

[2] A. Roberts and A. Charlesworth, "Future plea for infirmary: a modeling study," Journal of Healthcare system, vol. 80, no. 1, p. 20, 2012.

[3] A.H. Ramli, "Effects of Service Delivery Systems on the Image of Type C Private Hospitals in Makassar," Business \& Arrangement Watchfulness Media, vol. 13, no. 2, pp. 147-168, 2013.

[4] A.H. Ramli, "The Effect of Physical Support Facilities at Stella Maris Hospital on the Image of Stella Maris Hospital in Makassar," Progressive Journal, vol. 5, no. 02, pp. 1-22, 2012.

[5] A.H. Ramli, "Patient Satisfaction, Hospital Image And Patient Loyalty In West Sulawesi Province," Business And Entrepreneurial Review, vol. 16, no. 2, pp. 137-150, 2017

[6] A.H. Ramli, "Patient Trust On The Hospital Service Delivery System," Business And Entrepreneurial Review, vol. 16, no. 1, pp. 17-30, 2016.
[7] A.H. Ramli, "Manage Of Job Stress And Measure Employee Performance In Health Services," Business And Entrepreneurial Review, vol. 18 , no. 1, pp. 145-156, 2018.

[8] D. Goleman, R.E. Boyatzis, and A McKee, Primal Leadership: Unleashing the Power of Emotional Intelligence. Harvard Business Press, 2013

[9] A. Carmeli, "The Relationship Midst Emotional Intelligence and Work Attitudes, Conduct and Outcomes: An Examination Among Senior Arrangers," Journal of Arrangerial Psychology, vol. 18, no. 7/8, pp.788 $-814,2003$

[10] S.S. Putri and A.H. Ramli, "Determinant of Employee Performance at PT. Kinden Indonesia in Jakarta," Proceedings of the 3rd National Scholar Seminar in 2017, Trisakti University Watchfulness Institute, pp. 239-243, 2017.

[11] A.H. Ramli, "Organizational commitment and Employee Performance at Distributor Company,” Business And Entrepreneurial (BER), vol. 17, no. 1 , pp. 17-30, 2017

[12] A.H. Ramli and E.T. Maniagasi, "Employee Performance of Jayapura II Regional Hospital," Proceedings of the 4th National Seminar of Scholars in 2018, Watchfulness Institute of Trisakti University, pp. 805-810, 2018

[13] A.H. Ramli, "Compensation, Job Satisfaction and Employee Performance in Health Services," Business And Entrepreneurial (BER) vol. 18 , no. 1, pp.85-94, 2018.

[14] A.H. Ramli, "Work Environment, Job Satisfaction and Employee Performance in Health Services," Business and Entrepreneurial Review, vol. 19 , no. 1, pp. 29-42, 2019

[15] A.H. Ramli, "The Effect of Organizational Culture on Employee Performance Through Job Satisfaction," Business and Entrepreneurial Review, vol. 19, no. 2, pp. 157-168, 2019.

[16] A.S. Drigas and C. Papoutsi, "A New Layered Model on Emotional Intelligence. Conductal Sciences," Journal of Psychology, vol. 8, no. 5, p. 45,2018

[17] R.J. Sternberg and S.B. Kaufman, The Cambridge Handbook of Intelligence. New York, NY: Cambridge University Press, 2011.

[18] J.D. Mayer, P. Salovey, and D.R. Caruso, "Emotional Intelligence: Theory, findings and implications," Psychological Inquiry, vol. 15, no. 3, pp. 197-215, 2004.

[19] N.S. Schutte, J.M. Malouff, and E.B. Thorsteinsson, "Increasing emotional intelligence through training: Current status and future directions," International Journal of Emotional Education, vol. 5, no. 1, pp. 56-72, 2013.

[20] J.M.N. Karimi, "Effects of emotional intelligence on employee performance in the hotel industry in Kenya," The International Journal of Business \& Arrangement, vol. 2, no. 1, pp. 6-14, 2014.

[21] H.G. Cekmecelioglu, A. Gunsel, and T. Ulutas, "Effects of emotiona intelligence on job satisfaction: An empirical study on call center employees," Procedia - Social and Conductal Sciences, vol. 58, pp. 363369, 2012.

[22] T.A. Judge, C.L. Hulin, and R.S. Dalal, Job satisfaction and job govern In S.W.J. Kozlowski, The Oxford handbook of industrial and organizational psychology. New York: Oxford University Press, 2012.

[23] M. Miah and N. Hafid, "A Review Study of the Human Resource Arrangement Practices on Job Satisfaction of Hotel Industry Employees of Malaysia," International Journal of Human Resource Studies, vol. 9 , no. 3, pp. 75-85, 2019.

[24] M. Haile and P. Premanandam, "Employees' job satisfaction in Ethiopia: A Comparative study of selected public and private sectors in the Woldia district," International Journal of Applied Watchfulness, vol. 3, no. 4, pp. 19-25, 2017.

[25] J. Singh and M. Jain, "A Study of Employees' Job Satisfaction and It Impact on their Performance," Journal of the Indian Watchfulness, vol 4, pp. 105-1, 2013.

[26] M. Sarasvathy, Identifying factors that influence job performance among employees in oil palm plantations. Open University Malaysia, 2013. 
[27] M. Gupta, "Employees Satisfaction towards Monetary Compensation Practices," Global Journal of Finance and Arrangement, vol. 6, no. 8, pp. 757-764, 2014.

[28] J.G. Caillier, "Factors governing job performance in public agencies," Public Performance \& Arrangement Review, vol. 34, no. 2, pp. 139 $165,2010$.

[29] R.K. Pradhan and L.K. Jena, "Employee performance at workplace: Draughtual model and empirical validation," Business Perspectives and Watchfulness, vol. 5, no. 1, pp. 69-85, 2017.

[30] Y.P. Peng, "Job satisfaction and job performance of university librarians: A disaggregated," 2014

[31] Mahdinezhad, Shahhosseini, Kotamjani, Bing and Hashim, "Emotional Intelligence and Job Performance: A Study among Malaysian Administrators," International Journal of Academic Watchfulness in Business and Social Sciences, vol. 7, no. 6, 2017.

[32] N. Shamsuddin and R.A. Rahman, "The Relationship midst Emotional Intelligence and Job Performance of Call Center Agents," Procedia Social and Conductal Sciences, vol. 129, pp. 75- 81, 2014.

[33] M. Vahidi, H.N. Areshtanab, and M.A. Arshadi Bostanabad, "The Relationship midst Emotional Intelligence and Perception of Job Performance among Nurses in North West of Iran," Scientifica, pp. 1-5, 2016.

[34] Shukla and R. Adhikari, "Emotional Intelligence and Job Satisfaction: An Empirical Investigation," Amity Global HRM journal, vol. 6, pp. 5461, 2016.

[35] N.A. Nahid, "Trainers: emotional intelligence, job satisfaction, and organizational commitment," Journal of Workplace Learning, vol. 24 no. 4, pp. 256-269, 2012.

[36] C.S. Long, M. Yaacob, and T.W. Chuen, "The Impact of Emotiona Intelligence on Job Satisfaction among Teachers," International Journal of Arrangement, Accounting and Economics, vol. 3, no. 8, pp. 544-552, 2016.

[37] M. Shaju and D. Subhashini, "A study on the impact of Job Satisfaction on Job Performance of Employees working in Automobile Industry, Punjab, India," Journal of Arrangement, vol. 9, no. 1, 2016.

[38] B. Vermeeren, B. Kuipers, and B. Steijn, "Does leadership style make a difference? HRM linking, job satisfaction, and organizational performance," Review of Public Administration Personnel, vol. 34, no. 2, pp. 174-195, 2014.
[39] M.R. Khan, Ziauddin, F.A. Jam, and M.I. Ramay, "The impact of Organizational commitment on employee job performance," European Journal of Social Sciences, vol. 15, no. 3, pp. 292-298, 2010.

[40] I. Vratskikh, R. Masa'de, M. Al-Lozi, and M. Maqableh, "The Impact of Emotional Intelligence on Job Performance via the Mediating Role of Job Satisfaction," International Journal of Business and Arrangement, vol. 11 , no. 2 , pp. 69-91, 2015.

[41] M. Pugno and S. Depedri, "Job Performance and Job Satisfaction: An Integrated Survey," Department of Economics Working Papers: University of Trento, Italy, 2009.

[42] J.F. Hair, W.C. Black, B.J. Babin, and R.E. Anderson, Multivariate Data Analysis. New York: Pearson, 2010.

[43] C.S. Wong and K.S. Law, "The Effects of Leader and Follower Emotional Intelligence on Performance and Attitude: An Exploratory Study," The Leadership Quarterly, vol. 13, no. 3, pp. 243-274, 2002.

[44] A.J. Cellucci and D.L. Devries, "Measuring arrangerial satisfaction: A manual for the MJSQ," Journal of Technical Report, vol. 11, no. 5, 1978.

[45] A. Eckhardt, S. Laumer, C. Maier, and T. Weitzel, "The Effect of personality on IT personnel's job-concerned attitudes: Estabilishing a dispositional model of turnover intention across IT job types," Journal of Information Technology, pp. 48-66, 2016.

[46] S. Arikunto, Watchfulness Procedure, A Practice Approach. Jakarta: Rineka Cipta, 2013.

[47] P. Holmes-Smith, L. Coote, and E. Cunningham, Structural Equation Modeling: From the Fundamentals to Advanced Topics. Melbourne: SREAMS, 2006.

[48] A.H. Ramli, "Fit Person-Organization in the Marketing Distribution Chain," Journal of Arrangement and Marketing Services, vol. 12, no. 1, pp. 77-92, 2019

[49] A.H. Ramli and R. Yudhistira, "Effect of Career Development on Employee Performance through Organizational Commitment at PT. Infomedia Solusi Humanika in Jakarta," Proceedings of the 4th National Scholarship in 2018, Trisakti University Watchfulness Institute, pp. 811816, 2018.

[50] A.H. Ramli and S. Mariam. "Organisational Commitment And Job Performance In Banking Industry," International Journal of Scientific \& Technology Watchfulnes, vol. 9, no. 3, 2020. 